\title{
IZRAVNA PRIMJENA PRAVILA UFEU-A I NAČELA PRIMARNOG PRAVA UNIJE NA DODJELE UGOVORA O JAVNOJ NABAVI
}

Sažetak:

\begin{abstract}
Pravni horizont područja javne nabave nije ograničen na Zakon o javnoj nabavi i europske direktive o javnoj i sektorskoj nabavi, odnosno koncesijama. On uključuje $i$ određena pravila i načela primarnog prava Unije koja se primjenjuju na sve dodjele ugovora o javnoj nabavi, kao što je to utvrdio Sud Europske unije u svojoj sudskoj praksi. Učlanku autor analizira razvoj sudske prakse Suda EU-a u pogledu primjene pravilâ UFEU-a te načela jednakog postupanja, nediskriminacije, transparentnosti i uzajamnog priznavanja na dodjele ugovora o javnoj nabavi. Povrede tih pravila $i$ načela mogu se sankcionirati u postupcima kontrole javne nabave u skladu s nacionalnim pravom, ali i u postupcima pred Sudom EU-a u povodu Komisijinih tužbi protiv država članica zbog povrede obveze.
\end{abstract}

Ključne riječi: javna nabava, načelajavne nabave, pravo Europske unije, obveza transparentnosti

\section{UVOD}

Sud Europske unije u sudskoj je praksi potvrdio da se na sve dodjele ugovora o javnoj nabavi, neovisno o primjenjivosti direktiva in concreto, primjenjuju pravila Ugovora, ponajprije ona o slobodama kretanja robe, usluga i poslovnog nastana, ali i određena načela primarnog prava Unije koja je Sud razvio na temelju tih sloboda. ${ }^{1}$ Sud je pritom uvijek naglašavao da to što su neki ugovori izrijekom izuzeti iz područja primjene direktiva o javnoj nabavi ${ }^{2}$ ne znači da su potpuno isključeni iz područja primjene prava Unije. ${ }^{3}$

* Danijel Stanković, mag. iur., Court of Justice of the European Union, Rue du Fort Niedergrünewald, Boulevard Konrad Adenauer, Kirchberg, L-2925 Luxembourg, Luxembourg. Adresa e-pošte: danijel.stankovic@curia.europa.eu. ORCID: https:// orcid.org/0000-0003-0551-7394

1 Vidjeti, primjerice, presude Telaustria (C-324/98, EU:C:2000:669) i Vestergaard (C-59/00, EU:C:2001:654).

2 Direktiva 2014/24/EU o javnoj nabavi i o stavljanju izvan snage Direktive 2004/18/EZ (SL 2014., L 94, str. 65. te ispravci SL 2015., L 275, str. 68. i SL 2016., L 311, str. 26, u daljnjem tekstu: Opća direktiva o javnoj nabavi); Direktiva 2014/25/EU o nabavi subjekata koji djeluju u sektoru vodnog gospodarstva, energetskom i prometnom sektoru te sektoru poštanskih usluga i stavljanju izvan snage Direktive 2004/17/EZ (SL 2014., 94, str. 243.), naziva se direktivom o sektorskoj nabavi jer se odnosi na posebne djelomično liberalizirane sektore u kojima je i dalje dominantan javni interes (u daljnjem tekstu: Direktiva o sektorskoj nabavi); Direktiva 2014/23/EU o dodjeli ugovorâ o koncesiji (SL 2014., L 94, str. 1. i ispravak SL 2015., L 114, str. 24.; u daljnjem tekstu: Direktiva o koncesijama); u cijelom tekstu opća i sektorska direktiva zajedno se nazivaju "direktive o javnoj nabavi”. 
U tom smislu i na samom početku Opće direktive o javnoj nabavi u uvodnoj izjavi 1. stoji: "Dodjela ugovora o javnoj nabavi od strane ili u ime nadležnih tijela država članica mora biti u skladu s načelima [UFEU-a], pogotovo s načelom slobodnog kretanja robe, slobode poslovnog nastana i slobode pružanja usluga, kao i s načelima koja iz toga proizlaze, poput načela jednakog postupanja, zabrane diskriminacije, međusobnog priznavanja, proporcionalnosti i transparentnosti."

Taj je tekst zapravo potvrda, moglo bi se reći, svojevrsne Komisijine "pobjede" nad državama članicama koje su se svim snagama borile protiv primjene načelâ primarnog prava na dodjele ugovora koje su same direktive izuzele iz svojeg područja primjene, ${ }^{5}$ ali to je samo posljedica već ustaljene hijerarhije pravnih normi prava Unije.

Iako se pravila Ugovora i osnovna načela javne nabave primjenjuje na sve dodjele, tim su načelima, dakako, prožete i same odredbe direktiva o javnoj nabavi i dodjeli koncesija. U tom se smislu u navedenoj uvodnoj izjavi 1. precizira da bi "u slučaju ugovora o javnoj nabavi iznad određene vrijednosti, trebalo [...] sastaviti odredbe za koordinaciju postupaka nacionalne nabave kako bi se osiguralo da ta [ista] načela ostvaruju praktični učinak te da se pri javnoj nabavi potiče tržišno natjecanje".

Valja napomenuti da - za razliku od odredaba direktiva - zakonodavstvo države članice ne treba izričito predviđati obvezu poštovanja tih načela, s obzirom na to da proizlaze iz primarnog prava. ${ }^{6}$ To stvara dodatan pritisak na javne naručitelje, ali i rizik pri odlučivanju o tome treba li neki ugovor dodijeliti u prilagođenom postupku javne nabave ili ne.

Razvoj navedenih načela započeo je podjednako u postupcima u povodu Komisijinih tužbi protiv država članica zbog povrede obveza iz Ugovora i u onima u povodu zahtjeva za prethodnu odluku u konkretnim sporovima između javnih naručitelja i natjecatelja odnosno ponuditelja. Pritom je bila riječ o (i) situacijama u kojima je sama država članica propisom ili upravnom praksom omogućila kršenje tih načela ili (ii) onima u kojima javni naručitelj u konkretnom postupku nije poštovao navedena načela. ${ }^{7}$

\section{PRIMJENA PRAVILA UGOVORA}

Kao što je već spomenuto, na sve dodjele ugovora o javnoj nabavi primjenjuju se odredbe Osnivačkih ugovora koji su kao međunarodni ugovori nadređeni ostalim izvorima prava Uni-

4 Slično je propisano i u članku 4. stavku 1. Zakona o javnoj nabavi (Narodne novine, broj 120/2016).

5 Vidjeti presudu Njemačka i dr./Komisija (T-258/06, EU:T:2010:214). U tom postupku usmjerenom protiv Komisijine Interpretativne komunikacije o pravu Zajednice primjenjivom na dodjele ugovora koje u cijelosti ili djelomice ne podliježu odredbama direktiva o javnoj nabavi (SL 2006., C 179, str. 2.; u daljnjem tekstu: Interpretativna komunikacija), tužitelji su bili Njemačka, Francuska, Austrija, Poljska, Nizozemska, Grčka, Ujedinjena Kraljevina i Europski parlament. Opći je sud odbacio njihovu tužbu s obrazloženjem da navedena komunikacija ne donosi nova pravila o sklapanju ugovora o javnoj nabavi koja bi prelazila obveze na temelju postojećeg prava Zajednice (t. 162. presude). Tužitelji nisu uložili žalbu pa je navedena presuda pravomoćna. Citirani tekst iz uvodne izjave 1. Opće direktive o javnoj nabavi nalazio se u točki 1.1. prvom odlomku Interpretativne komunikacije, s naslovom "Pravila i načela UEZ-a”, ali i u uvodnoj izjavi 9. Direktive 2004/17 i uvodnoj izjavi 2. Direktive 2004/18.

6 Presuda Komisija/Italija (C-412/04, EU:C:2008:102, t. 82.).

7 Vidjeti, primjerice, presude Medipac - Kazantzidis (C-6/05, EU:C:2007:337) i Komisija/Grčka (C-489/06, EU:C:2009:165). 
je. ${ }^{8}$ Pritom se ponajprije misli na načela slobodnog kretanja robe, slobode poslovnog nastana i slobode pružanja usluga, kao i ostala načela koja iz njih proizlaze.

\subsection{SLOBODA KRETANJA ROBE}

U prvi se mah Sud najčešće pozivao na slobodu kretanja robe i povezanu zabranu količinskih ograničenja uvoza i mjera s istovrsnim učinkom iz članka 34. UFEU-a jer su se konkretni predmeti odnosili na favoriziranje domaćih poduzetnika i proizvoda. Treba podsjetiti da su do 1992. na razini Unije direktivama bile uređene samo nabava radova (od 1971.) i nabava robe (od 1977.) ${ }^{9}$ pa je i to jedan od razloga da je težište sudske prakse bilo upravo na slobodi kretanja robe kao izravnom (nabava robe) ili neizravnom predmetu nabave (primjerice građevinski materijal u kontekstu nabave radova).

Sloboda kretanja robe - zabranom količinskih ograničenja uvoza i mjera s istovrsnim učinkom - podrazumijeva i načelo uzajamnog priznavanja koje jamči slobodno kretanje robe čak i bez donošenja posebnih mjera usklađivanja nacionalnih zakonodavstava država članica na razini Unije. ${ }^{10}$ Kako je to Sud u svojoj sudskoj praksi izrazio "i onda kada ne postoje mjere usklađivanja prava Unije, proizvodi koji su zakonito proizvedeni i stavljeni na tržište u državi članici moraju moći biti stavljeni na tržište u drugoj državi članici a da pritom ne budu podvrgnuti dodatnim provjerama [(načelo uzajamnog priznavanja)]. Nacionalni propis koji nameće takve provjere opravdan je samo ako je obuhvaćen [jednom od] iznimk[i] predviđen[ih] člankom 36. UFEU-a ili važnim zahtjevima koji su priznati sudskom praksom Suda te [ako] je u oba slučaja [prikladan osigurati] ostvarenje cilja koji se želi postići i [ako] ne prekoračuje ono što je nužno za postizanje tog cilja [(načelo proporcionalnosti)]". ${ }^{11}$

U dvama predmetima s kraja 80-ih godina, Sud je ocijenio da je talijanski propis kojim se omogućuje favoriziranje domaće proizvodnje protivan slobodi kretanja robe. ${ }^{12} \mathrm{U}$ skladu s tim propisom, određeni je postotak svih javnih nabava robe bio rezerviran za poduzetnike sa sjedištem na jugu Italije (tzv. regija Mezzogiorno). Sud je zaključio da takva odredba čini koli-

8 Craig, P.; de Búrca, G., EU Law: Text, Cases, and Materials, 6. izdanje, Oxford University Press, 2015., str. 111. U istom smislu određuje i članak 134. Ustava Republike Hrvatske (prema enumeraciji članaka u skladu s Izvješćem Ustavnog suda Republike Hrvatske, broj U-X-1435/2011 od 23. ožujka 2011.).

9 Na razini Unije, zakonodavna aktivnost u pogledu uređenja javne nabave započela je već šezdesetih godina 20. stoljeća, vidjeti Maciejewski, M., Ugovori o javnoj nabavi, Informativni članci o Europskoj uniji, Europski parlament, lipanj 2017., http://www. europarl.europa.eu/atyourservice/hr/displayFtu.html?ftuId=FTU-3.2.2.html, pristupljeno 29. rujna 2017. Najprije su donesene direktive 71/305/EEZ o javnoj nabavi radova i 77/62/EEZ o javnoj nabavi robe te 89/665/EEZ o postupcima kontrole (pravne zaštite). Zatim je devedesetih godina uslijedila daljnja liberalizacija pa su propisi o javnoj nabavi prošireni na nabavu usluga (Direktiva 92/50/EEZ) i na nabavu u području vodoopskrbe, energije, prijevoza i telekomunikacija (Direktiva 93/38/EEZ) dok su prve dvije direktive zamijenjene novima (direktive 93/36/EEZ i 93/37/EEZ). Sljedeći korak u regulaciji javne nabave bile su direktive 2004/17/EZ i 2004/18/EZ kada je liberalizacija obuhvatila i poštanske usluge. Te su direktive zamijenjene 2014. kada je donesen novi paket s direktivama 2014/23/EU, 2014/24/EU i 2014/25/EU koji sada uključuje i dodjelu koncesija (u daljnjem tekstu se sve te direktive općenito nazivaju: direktive o javnoj nabavi).

Vidjeti presudu Njemačka i dr./Komisija (T-258/06, EU:T:2010:214, t. 119.) i analogijom presudu, Rewe/ Bundesmonopolverwaltung für Branntwein (120/78, EU:C:1979:42, tzv. Cassis de Dijon).

11 Presuda Capoda Import-Export (C-354/14, EU:C:2015:658, t. 40.).

12 Presude Du Pont de Nemours Italiana (C-21/88, EU:C:1990:121) i Laboratori Bruneau/USL RM/24 di Monterotondo (C-351/88, EU:C:1991:304). 
činsko ograničenje uvoza, bez obzira na to što je u odnosu na inozemne favoriziran samo dio nacionalnih proizvođača, tj. oni sa sjedištem u navedenoj regiji. ${ }^{13}$ Pritom je Sud naglasio da to što se takva mjera eventualno može kvalificirati kao državna potpora ne isključuje primjenu zabrane količinskih ograničenja. Drugim riječima, što je zanimljivo s gledišta ovog rada, i mjerom državne potpore može se prekršiti navedena zabrana. ${ }^{14}$

U jednom ranijem predmetu Sud je pak primjenom svojih stajališta iz presude Cassis de Dijon $^{15}$ utvrdio da je Francuska odgovorna za povredu prava Unije postupanjem državne uprave za poštu i telekomunikacije koja je britanskom proizvođaču uporno odbijala izdati potvrdu o ispunjavanju tehničkih uvjeta koja se odnosila na automate za prodaju poštanskih maraka. ${ }^{16}$ Sud je zaključio da upravna praksa s određenim stupnjem ustrajnosti i općenitosti može činiti mjeru s istovrsnim učinkom kao količinsko ograničenje uvoza, čak i ako je riječ o postupanju prema samo jednom poduzetniku, posebice ako je riječ o tržištu na kojem djeluje samo nekoliko proizvođača. ${ }^{17}$ Naime, u tom slučaju nije bila riječ o konkretnoj nabavi, nego o prethodnom koraku bez kojeg se takvi automati nisu ni mogli ponuditi francuskoj pošti.

Kad su posrijedi situacije u kojima sami javni naručitelj krši navedena načela, Sud je također krajem 80-ih utvrdio da je Irska povrijedila svoje obveze na temelju Ugovora postupanjem naručitelja u postupku nabave radova na izgradnji vodovoda u gradu Dundalku, premda je konkretni ugovor bio izvan područja primjene tada mjerodavne Direktive 71/305 o javnoj nabavi radova. ${ }^{18}$ Naime, dokumentacijom za nadmetanje zahtijevalo se da cijevi od azbestnog cementa koje je trebalo ugraditi u sustav vodovoda moraju ispunjavati točno određeni irski normizacijski standard koji je u praksi ispunjavao samo jedan irski proizvođač. ${ }^{19} \mathrm{Na}$ temelju te odredbe dokumentacije za nadmetanje, naručitelj je odbio ponudu drugog irskog ponuditelja u kojoj je potonji naveo da će upotrijebiti cijevi španjolskog proizvođača koje su imale međunarodni certifikat ISO. ${ }^{20}$

Sud je zaključio da je stavljanje takve odredbe u dokumentaciju za nadmetanje bilo protivno zabrani količinskih ograničenja uvoza i mjera s istovrsnim učinkom. ${ }^{21}$ Iako je bila riječ o ugovoru izvan područja primjene tada mjerodavne direktive o javnoj nabavi radova, Sud je naglasio da se stavljanjem napomene "ili jednakovrijedan" u tehničke specifikacije - kako je to bilo predviđeno navedenom direktivom ${ }^{22}$ - omogućuje poštovanje tehničkih uvjeta a da se pritom isključi mogućnost da se ugovor unaprijed rezervira samo za ponuditelje s točno određenim, nacionalnim proizvodima.

\footnotetext{
13 Presuda Du Pont de Nemours Italiana (C-21/88, EU:C:1990:121, t. 11. do 14.).

14 Ibid.t. 20.

15 Presuda Rewe/Bundesmonopolverwaltung für Branntwein (120/78, EU:C:1979:42).

16 Presuda Komisija/Francuska (21/84, EU:C:1985:184).

17 Ibid.t. 11. do 13.

18 Presuda Komisija/Irska (45/87, EU:C:1988:435, t. 10.).

19 Ibid. t. 20.

$20 \quad$ Ibid. t. 4.

21 Ibid. t. 27. Sud je također izjavio da se takvom odredbom u dokumentaciji za nadmetanje gospodarske subjekte koji proizvode ili upotrebljavaju jednakovrijedne proizvode može odvratiti od sudjelovanja u postupku nabave, vidjeti točku 19. iste presude.

22 Obveza stavljanja napomene "ili jednakovrijedan" propisana je sada člankom 42. Opće direktive o javnoj nabavi, člankom 60. Direktive o sektorskoj nabavi i člankom 36. Direktive o koncesijama.
} 
Isto je potvrđeno u odnosu na odredbu dokumentacije za nadmetanje prema kojoj je danski javni naručitelj predvidio uvjet da se što je više moguće koristi danski materijal, roba široke potrošnje i radna snaga, ${ }^{23}$ kao i u odnosu na odredbu nizozemskog javnog naručitelja kojom je predmet nabave u dokumentaciji za nadmetanje opisan upućivanjem samo na jednog proizvođača (softver UNIX) bez navođenja napomene "ili jednakovrijedan". ${ }^{4}$

U vezi s mjerama kojima se nacionalna zakonodavstva usklađuju na razini Unije, načelo međusobnog priznavanja posebno je došlo do izražaja u slučaju ustaljene prakse grčkih bolnica, prema kojoj su u postupcima javne nabave robe uporno odbijale određene medicinske proizvode s oznakom CE, pozivajući se pritom na zaštitu javnog zdravlja. ${ }^{25} \mathrm{Tu}$ je konkretno bila riječ o primjeni Direktive $93 / 42^{26}$ prema čijem članku 4. "[d]ržave članice ne smiju stvarati nikakve prepreke stavljanju u promet ili stavljanju u uporabu unutar svoga područja proizvoda koji nose CE oznaku sukladnosti [...], što znači da je ocijenjena njihova sukladnost [...]”. Naime, u njezinu članku 8. predviđena je, u biti u skladu s člankom 114. stavkom 10. UFEU-a, ${ }^{27}$ zaštitna klauzula kojom se državama članicama odobrava da zbog jednog ili više razloga navedenih u članku 36. UFEU-a, ${ }^{28}$ koji svakako ne smiju biti gospodarske naravi, poduzmu privremene mjere ograničavanja slobode kretanja koje podliježu postupku nadzora Unije.

Prema navedenom članku 8. stavku 1., država članica u takvom je slučaju "dužna poduzeti sve odgovarajuće privremene mjere da povuče takve proizvode iz prometa ili zabrani ili ograniči njihovo stavljanje u promet ili stavljanje u uporabu", ali i odmah obavijestiti Komisiju o takvim mjerama. Međutim, grčki javni naručitelji nisu poštovali postupak predviđen zaštitnom klauzulom, nego su izravno odbijali ponude s određenim medicinskim proizvodima. ${ }^{29}$ Sud je utvrdio da je Grčka povrijedila svoje obveze na temelju Ugovora, ocijenivši da je riječ o upravnoj praksi s određenim stupnjem ustrajnosti i općenitosti. ${ }^{30}$

\subsection{SLOBODA POSLOVNOG NASTANA I SLOBODNO PRUŽANJE USLUGA}

U jednom od prvih predmeta koji su se odnosili na slobodu poslovnog nastana i slobodno pružanje usluga u kontekstu javne nabave, bila je riječ o talijanskom propisu prema kojem su

23 Presuda Komisija/Danska (C-243/89, EU:C:1993:257).

24 Presuda Komisija/Nizozemska (C-359/93, EU:C:1995:14).

25 Presude Medipac - Kazantzidis (C-6/05, EU:C:2007:337) i Komisija/Grčka (C-489/06, EU:C:2009:165).

26 Direktiva Vijeća 93/42/EEZ od 14. lipnja 1993. o medicinskim proizvodima (SL 1993, L 169, str. 1.) (SL, posebno izdanje na hrvatskom jeziku, poglavlje 13., svezak 53., str. 5.).

27 Članak 114. (bivši članak 95. UEZ-a) čini posebnu pravnu osnovu za donošenje mjera Unije u redovnom zakonodavnom postupku radi usklađivanja zakonodavstava država članica s ciljem uspostave i funkcioniranja unutarnjeg tržišta. U tom se kontekstu stavkom 10. predviđa obveza uključivanja "zaštitne klauzule" (eng. safeguard clause, franc. clause de sauvegarde, njem. Schutzklausel) u takve mjere kojom se u odgovarajućim slučajevima omogućava odstupanje od mjera usklađivanja.

“Odredbe članaka 34. i 35. ne isključuju zabrane ili ograničenja uvoza, izvoza ili provoza robe koji su opravdani razlozima javnog morala, javnog poretka ili javne sigurnosti; zaštite zdravlja i života ljudi, životinja ili biljaka; zaštite nacionalnog blaga umjetničke, povijesne ili arheološke vrijednosti; ili zaštite industrijskog i trgovačkog vlasništva. Međutim, te zabrane ili ograničenja ne smiju biti sredstvo proizvoljne diskriminacije ili prikrivenog ograničavanja trgovine među državama članicama.” 
se ugovori o izradi informatičkih sustava za potrebe javne uprave mogli dodijeliti isključivo trgovačkim društvima u kojima država ili javni sektor izravno ili neizravno imaju većinu ili sav temeljni kapital. ${ }^{31}$

Sud je pošao od načela jednakog postupanja koje je prema njegovu shvaćanju poseban izraz slobode poslovnog nastana i slobodnog pružanja usluga. ${ }^{32}$ Iako je bila riječ o mjeri koja se jednako ${ }^{33}$ primjenjivala i na talijanska i na inozemna društva iz drugih država članica, Sud je zaključio da navedeni propisi u biti favoriziraju talijanska društva. ${ }^{34}$ Pritom Sud nije prihvatio argumentaciju prema kojoj bi ti propisi bili opravdani zbog nužnosti nadzora nad izvršavanjem ugovora i zbog nepredvidljivih čimbenika u trenutku potpisivanja ugovora, kao i radi zaštite tajnosti podataka, s obzirom na to da je Italija imala na raspolaganju odgovarajuće pravne institute, poput ugovornih obveza pa čak i predviđanja kaznene odgovornosti za povrede tajnosti. ${ }^{35}$ Sud također nije prihvatio argument prema kojem bi izrada informatičkih sustava i upravljanje njima bile djelatnosti na koje se primjenjuje iznimka od slobode poslovnog nastana i slobodnog pružanja usluga kad su posrijedi djelatnosti povezane s izvršavanjem javnih ovlasti iz članka 51. u vezi s člankom 62 . UFEU-a. ${ }^{36}$ Sud nije prihvatio ni argument prema kojem su, s obzirom na svoj cilj i tajnost podataka, navedene djelatnosti obuhvaćene talijanskim javnim poretkom u smislu članka 52. stavka 1. UFEU-a. ${ }^{37}$

Slično je prošao i talijanski propis prema kojem je ugovaratelj morao 15 do $30 \%$ radova povjeriti poduzetnicima sa sjedištem u regiji u kojoj se izvršavaju radovi, tj. pri odabiru ugovaratelja prednost se morala dati zajednicama ponuditelja u kojima sudjeluju poduzetnici koji glavninu svoje djelatnosti obavljaju baš u toj regiji. ${ }^{38}$ Sud je zaključio da se takvim propisom krši slobodno pružanje usluga diskriminacijom na temelju državljanstva jer se u biti pogodovalo sudjelovanju samo talijanskih podizvođača, neovisno o tome što se navedeni propis jednako primjenjivao i na strana i na talijanska društva iz ostatka zemlje. ${ }^{39}$

U trećem predmetu, u kojem je Sud također utvrdio povredu slobode poslovnog nastana i slobodnog pružanja usluga, riječ je bila o dodjeli koncesija za sustave automatizacije igre lota prilikom koje je predviđeno ograničenje isključivo u korist gospodarskih subjekata i njihovih

31 Presuda od 5. prosinca 1989., Komisija/Italija (C-3/88, EU:C:1989:606).

32 Ibid. t. 8. U istoj točki Sud podsjeća na to da načelo jednakog postupanja ne zabranjuje samo izravnu diskriminaciju na temelju državljanstva, nego i sve druge prikrivene oblike diskriminacije koji primjenom drugih kriterija razlikovanja u stvarnosti dovode do istog rezultata. Valja naglasiti da načelo jednakog postupanja svoj pravni temelj ima u zabrani diskriminacije na temelju državljanstva predviđenoj člankom 18. UFEU-a, kao što proizlazi i iz presude Boussac Saint-Frères (22/80, EU:C:1980:251, t. 9.), na koju se Sud pozvao u istoj točki presude.

Za razliku u analizi sukladnosti jednako primjenjivih nacionalnih mjera s člankom 34. UFEU-a vidjeti detaljnije Ćapeta, T.; Rodin, S., Osnove prava Europske unije na temelju Lisabonskog ugovora, Narodne novine, Zagreb, travanj 2010., str. 93. et seq.

e teoriji su se u tim postupcima javne nabave mogla javiti i inozemna društva u kojima je član bila Italija ili subjekt iz njezina javnog sektora, ali u tom trenutku nije postojalo nijedno takvo društvo, vidjeti presudu Komisija/Italija (C-3/88, EU:C:1989:606, t. 9.).

Ibid. t. 14. i 15. U drugom dijelu presude, u pogledu primjene iznimke iz tada mjerodavne direktive o javnoj nabavi robe, Sud je također zaključio da navedene djelatnosti nisu javne usluge, vidjeti točke 25. i 26. 
zajednica "s većinskim javnim sudjelovanjem". ${ }^{40}$ Sud je zaključio da je riječ o tehničkim djelatnostima u vezi s uspostavljanjem i upravljanjem sustava automatizacije koje podrazumijevaju isporuku usluga i robe, a ne koncesiji u pravom smislu riječi, s obzirom na to da nije preneseno obavljanje javne vlasti ili zadaće organiziranja igre lota. ${ }^{41}$

Sud je, nadalje, u kontekstu obavljanja javnih radova također potvrdio da gospodarski subjekt iz jedne države članice smije dovesti svoje radnike radi izvršenja potrebnih radova u drugu državu članicu bez ograničenja u vezi sa zapošljavanjem stranaca i bez ishođenja radne dozvole. ${ }^{42}$ Naime, prema članku 57. drugom stavku UFEU-a (tadašnji članak 60. UEEZ-a), “[n] e dovodeći u pitanje odredbe poglavlja o pravu poslovnog nastana, osoba koja pruža neku uslugu može, u svrhu pružanja te usluge, privremeno obavljati svoju djelatnost u državi članici u kojoj se usluga pruža, i to prema istim uvjetima koje ta država propisuje za svoje državljane". ${ }^{43}$ Nasuprot tomu, Sud je zaključio da države članice u skladu s pravom Unije na takve radnike smiju proširiti primjenu svojeg radnog zakonodavstva i kolektivnih ugovora. ${ }^{44}$

Na kraju, u vezi sa slobodom poslovnog nastana i slobodnim pružanjem usluga, načelo uzajamnog priznavanja podrazumijeva uzimanje u obzir svih diploma, svjedodžbi i drugih dokaza kao i relevantnog iskustva dotične osobe uspoređivanjem, s jedne strane, vještina potvrđenih tim dokazima i iskustvom i, s druge strane, znanja i kvalifikacija koje zahtijeva nacionalno zakonodavstvo. ${ }^{45}$ Riječ je o načelu primarnog prava koje nije izgubilo svoju pravnu vrijednost donošenjem direktiva o uzajamnom priznavanju diploma pa države članice u tom području moraju poštovati svoje obveze koje proizlaze iz slobode poslovnog nastana i slobodnog pružanja usluga. ${ }^{46}$

40 Presuda od 26. travnja 1994., Komisija/Italija (C-272/91, EU:C:1994:167, t. 3. i 13.). Iz Komisijine tužbe proizlazi da je bila riječ o sudjelovanju u temeljnom kapitalu gospodarskih subjekata (eng. majority of whose capital, considered individually or in aggregate, was publicly owned, franc. dont le capital social, pris isolément ou dans son ensemble, est à participation publique majoritaire, njem. deren Gesellschaftskapital sich einzeln oder insgesamt mehrheitlich in öffentlicher Hand befindet). Ibid. t. 6. do 12., 22. do 25. i 32.

Presuda Rush Portuguesa (C-113/89, EU:C:1990:142, t. 19.). Zanimljivo je primijetiti da je Sud navedeno stajalište zauzeo puno prije donošenja Direktive 96/71/EZ Europskog parlamenta i Vijeća od 16. prosinca 1996. o upućivanju radnika u okviru pružanja usluga (SL 1997., L 18, str. 1.) (SL, posebno izdanje na hrvatskom jeziku, poglavlje 5., svezak 5., str. 127.).

43 Slično je određeno i u članku 612. stavku 3. Zakona o trgovačkim društvima (Narodne novine, broj 111/1993, 1999, 52/2000, 118/2003, 107/2007, 146/2008, 137/2009, 125/2011, 152/2011, 111/2012, 68/2013, 110/2015), pod naslovom "Poslovanje u Republici Hrvatskoj", koji glasi: "Obavljanjem djelatnosti ne smatra se primjerice povremeno ili jednokratno obavljanje djelatnosti, odnosno obavljanje pojedinog posla (pojam slobode pružanja usluga u skladu s pravnom stečevinom EU). Je li riječ o trajnom obavljanju djelatnosti u smislu prethodnog stavka ovoga članka, ocjenjuje se prema okolnostima konkretnog slučaja." U prethodnom stavku 2. određeno je pak da "[i]nozemna trgovačka društva i inozemni trgovci pojedinci ne mogu trajno obavljati djelatnosti na području Republike Hrvatske dok tamo ne osnuju podružnicu." S druge strane, Zakon o strancima (Narodne novine broj 130/2011, 74/2013) čini se ne pokriva sve situacije obavljanja poslova u skladu sa slobodom pružanja usluga i, štoviše, zahtijeva ispunjavanje dodatnih formalnosti, primjerice, ishođenje potvrde o prijavi rada na temelju članka 82. tog Zakona, ali i vremensko ograničenje takvog rada do 90 dana. Presuda Rush Portuguesa (C-113/89, EU:C:1990:142, t. 18.). Vidjeti također presude Seco/EVI (62/81 i 63/81, EU:C:1982:34, t. 14.); Portugaia Construções (C-164/99, EU:C:2002:40, t. 21.) i Laval (C-341/05, EU:C:2007:809, t. 57.).

45 Presuda Njemačka i dr./Komisija (T-258/06, EU:T:2010:214, t. 119.); vidjeti i analogijom presudu Brouillard, (C-298/14, EU:C:2015:652, t. 54. i navedenu sudsku praksu).

46 Presuda Njemačka i dr./Komisija (T-258/06, EU:T:2010:214, t. 120. i navedena sudska praksa). Opći se sud pozvao, među ostalim, i na članak 53. UFEU-a (bivši članak 47. UEZ-a) koji čini posebnu pravnu osnovu za donošenje direktiva za međusobno priznavanje diploma, svjedodžbi i ostalih dokaza o formalnim kvalifikacijama te obavljanje samostalnih profesija. 


\section{NAČELO NEDISKRIMINACIJE, NAČELO JEDNAKOG POSTUPANJA I OBVEZA TRANSPARENTNOSTI}

Sud je u kontekstu javne nabave načelima koja su se razvila u vezi s temeljnim slobodama dao i novu, znatno širu dimenziju. Osobito je značajna obveza transparentnosti koju je Sud izveo iz načela nediskriminacije i jednakog postupanja prema ponuditeljima odnosno natjecateljima u postupcima javne nabave. ${ }^{47}$ Pritom, između načela nediskriminacije i načela jednakog postupanja nema posebne razlike. Prije je riječ o dvama aspektima istog instituta kojemu je cilj izbjeći nejednako postupanje u usporedivim situacijama odnosno jednako postupanje u različitim situacijama. ${ }^{48}$ Zato se u nekim presudama spominje samo načelo nediskriminacije, ${ }^{49}$ a u nekima oba navedena načela. ${ }^{50}$ Pravila jednakog postupanja zabranjuju ne samo očitu diskriminaciju nego i sve oblike prikrivene diskriminacije koji, primjenom drugih kriterija razlikovanja, dovode do istog rezultata. ${ }^{51}$

Otkako je Povelja Europske unije o temeljnim pravima u skladu s Lisabonskim ugovorom postala pravno obvezujući dokument, načelo jednakog postupanja sada je njezinim člankom 20., naslovljenim “Jednakost pred zakonom”, izričito predviđeno kao načelo primarnog prava. $^{52}$

U prvim presudama, Sud je utvrdio da, premda ga direktive o javnoj nabavi izričito ne navode, obveza poštovanja načela jednakog postupanja odgovara samoj biti tih direktiva kojima je cilj razviti učinkovito tržišno natjecanje u području javnih nabava. ${ }^{53}$

Kako se navodi u Komisijinoj Interpretativnoj komunikaciji iz 2006., načela jednakog postupanja i nediskriminacije podrazumijevaju, među ostalim, (i) nediskriminirajući opis predmeta nabave koji, u slučaju nabave robe, uvijek mora sadržavati napomenu o prihvatljivosti jednakovrijednog proizvoda, što je posljedica i slobode kretanja robe, (ii) jednak pristup gospodarskih subjekata iz svih država članica, bez nametanja uvjeta koji dovode do izravne ili neizravne diskriminacije, poput zahtjeva o poslovnom nastanu u državi članici ili regiji u kojoj se nalazi javni naručitelj, ${ }^{54}$ (iii) uzajamno priznavanje diploma, svjedodžbi i drugih dokaza for-

47 Ovisno o vrsti ili fazi postupka sudionici postupka nazivaju se različito. U otvorenom se postupku gospodarski subjekti koji sudjeluju u postupku javne nabave nazivaju "ponuditelji", a u ograničenom postupku riječ je o "natjecateljima" koji podnose zahtjev za sudjelovanje u postupku. Nakon provjere sposobnosti natjecatelja (opće provjere i posebne, npr. testiranjem), šalje im se poziv na dostavu ponuda. Dostavom ponuda, dotadašnji natjecatelji postaju ponuditelji.

Vidjeti analogijom presudu Španjolska/Komisija (T-461/13, EU:T:2015:891, t. 168.).

Presuda Telaustria (C-324/98, EU:C:2000:669, t. 60.).

Presuda pressetext Nachrichtenagentur (C-454/06, EU:C:2008:351, t. 32. i navedena sudska praksa).

Presuda Hervis Sport- és Divatkereskedelmi (C-385/12, EU:C:2014:47, t. 30.).

Presuda Léger (C-528/13, EU:C:2015:288, t. 43.).

Presude Komisija/Danska (C-243/89, EU:C:1993:257, t. 37.) i Komisija/Belgija (C-87/94, EU:C:1996:161, t. 51.). Cilj “otvaranja nacionalnih nabava" prvi je put u primarnom pravu izražen u članku 130.f stavku 2. UEZ-a koji je dodan Jedinstvenim europskim aktom iz 1986. (SL 1987., L 169, str. 1.), sada članak 179. stavak 2. UFEU-a.

Kao dobar primjer diskriminacije na temelju zahtjeva poslovnog nastana može poslužiti postupak javne nabave zdravstvenih usluga respiratorne terapije koji je bio predmet ocjene Suda u presudi Contse (C-234/03, EU:C:2005:644) i u kojem je kao uvjet za sudjelovanje bilo predviđeno da ponuditelj mora imati ured u središtu dotične teritorijalne jedinice, otvoren 8 sati na dan, pet dana u tjednu; tehničke su specifikacije pak predviđale da ponuditelj mora imati najmanje dva postrojenja za proizvodnju kisika na udaljenosti do $1000 \mathrm{~km}$ od provincije i najmanje jedno postrojenje za opremanje boca i jedno za punjenje boca, oba na udaljenosti do $1000 \mathrm{~km}$ od dotične teritorijalne jedinice; u slučaju da jedan ili više ponuditelja postignu jednak broj 
malnih kvalifikacija, (iv) primjerene rokove za iskazivanje interesa ili podnošenje ponuda i (v) transparentan i objektivan pristup prema sudionicima javne nabave. ${ }^{55}$ Ukratko, načela jednakog postupanja i nediskriminacije primjenjuju se na sve aspekte i faze postupka javne nabave, primjerice i na tehničko pitanje ponderacije pojedinih kriterija u ocjenjivanju ponude, ${ }^{56}$ izračuna kriterija ekonomski najpovoljnije ponude, ${ }^{57}$ isključenja izuzetno niskih ponuda, ${ }^{58}$ izmjene dokumentacije o nabavi nakon objave poziva na nadmetanje, ${ }^{59}$ ograničavanje podizvođenja ${ }^{60} \mathrm{i}$ mnoge druge. Ponuditelji moraju biti ravnopravni i u trenutku kada pripremaju svoje ponude i u trenutku kada ih javni naručitelji ocjenjuju. ${ }^{61}$

Sud je na temelju tih dvaju načela utvrdio da se na javne naručitelje primjenjuje i obveza transparentnosti, bez obzira na to prelazi li vrijednost predmeta nabave propisane europske pragove ili je riječ o izuzetom ugovoru (kao što je, primjerice, bio slučaj s koncesijama do donošenja Direktive o koncesijama 2014.), pod dodatnim uvjetom da konkretni predmet nabave uključuje određeni prekogranični interes; naime, upravo obveza transparentnosti omogućuje javnom naručitelju poštovanje načela jednakog postupanja i nediskriminacije. ${ }^{62}$ To je tumačenje, međutim, izazvalo najviše otpora među državama članicama, ali i nedoumica u vezi s opsegom zahtjevâ na temelju te obveze.

Kao što je to Sud izrazio u svojoj sudskoj praksi, cilj obveze transparentnosti jest jamčiti svakom potencijalnom ponuditelju odgovarajuću razinu publiciteta koja omogućava razvoj tržišnog natjecanja i nadzor nepristranosti postupaka javne nabave. ${ }^{63}$ Ona podrazumijeva to da poduzetnik sa sjedištem u drugoj državi članici mora imati pristup odgovarajućim informacijama u vezi s nekim ugovorom prije njegove dodjele kako bi, ako to želi, mogao izraziti svoj interes za sklapanje tog ugovora. ${ }^{64}$ Ako za takav ugovor postoji određeni prekogranični interes, dodjela ugovora bez ikakve transparentnosti čini razliku u postupanju na štetu poduzetnika sa sjedištem u drugim državama članicama koji bi mogli biti zainteresirani; štoviše, ako nema objektivnog opravdanja, takvom razlikom u postupanju čini se neizravna diskriminacija na temelju državljanstva, zabranjena člancima 49. i 56. UFEU-a. ${ }^{65}$

bodova s trenutačnim pružateljem usluge, ugovor je trebalo sklopiti s potonjim. Nijedan od navedenih zahtjeva nije prošao test proporcionalnosti Suda.

55 Točka 2.2. Interpretativne komunikacije, naslovljena "Dodjela ugovora".

56 Presuda Dimarso (C-6/15, EU:C:2016:555).

57 Presuda Španjolska/Komisija (T-402/06, EU:T:2013:445).

58 Presude Costanzo (103/88, EU:C:1989:256) i SECAP i dr. (C-147/06 i C-148/06, EU:C:2008:277).

59 Presuda Borta (C-298/15, EU:C:2017:266).

60 Presude Wrocław - Miasto na prawach powiatu (C-406/14, EU:C:2016:562); Borta (C-298/15, EU:C:2017:266) i Partner Apelski, Dariusz (C-324/14, EU:C:2016:214).

61 Presuda Dimarso (C-6/15, EU:C:2016:555, t. 22.).

62 Presude Komisija/Belgija (C-87/94, EU:C:1996:161, t. 33., 54. i 91.); Unitron Scandinavia i 3-S (C-275/98, EU:C:1999:567, t. 31.); Telaustria (C-324/98, EU:C:2000:669, t. 61.); Parking Brixen (C-458/03, EU:C:2005:605, t. 49.); ANAV (C-410/04, EU:C:2006:237, t. 21.); Medipac - Kazantzidis (C-6/05, EU:C:2007:337, t. 33.); Njemačka i dr./Komisija (T-258/06, EU:T:2010:214, t. 76.) i Borta (C-298/15, EU:C:2017:266, t. 36.).

63 Presuda Telaustria (C-324/98, EU:C:2000:669, t. 62.).

64 Presude Coname (C-231/03, EU:C:2005:487, t. 21.) i Njemačka i dr./Komisija (T-258/06, EU:T:2010:214, t. 78.).

65 Presude Telaustria (C-324/98, EU:C:2000:669, t. 61.); Coname (C-231/03, EU:C:2005:487, t. 17. do 19.) i Komisija/Irska (C507/03, EU:C:2007:676, t. 29. do 31.). Međutim, Sud je u potonjoj presudi također naglasio da Komisija u postupku protiv države članice zbog povrede obveze mora dokazati da je konkretan ugovor o javnoj nabavi bio od određenog prekograničnog 
Kao kriteriji na temelju kojih se može utvrditi određeni prekogranični interes mogu poslužiti, primjerice, (i) značajna procijenjena vrijednost ugovora, (ii) razina potrebnog tehničkog znanja ili (iii) mjesto izvođenja radova koje s obzirom na svoj položaj može biti privlačno inozemnim izvođačima. ${ }^{66}$ Također, slab gospodarski značaj projekta može upućivati na nepostojanje takvog interesa. ${ }^{67}$

Prijeporno je pitanje sadržaja i opsega transparentnosti. U svojoj Interpretativnoj komunikaciji iz 2006., Komisija navodi da se obveza transparentnosti može ispuniti jedino objavom dovoljno pristupačnog oglasa prije dodjele ugovora, pri čemu smatra da ostale prakse, poput kontaktiranja potencijalnih ponuditelja, pasivnog oglašavanja pri kojem javni naručitelj samo odgovara na upite natjecatelja koji su negdje drugdje doznali za namjeravanu dodjelu ugovora ili upućivanje na medijske izvještaje, parlamentarne ili političke rasprave ili kongrese, nisu dovoljne. ${ }^{68}$ Kad je riječ o načinima objave oglasa, Komisija nadalje navodi mogućnosti poput interneta, državnog službenog lista ili službenog lista Unije (TED - Tenders Electronic Daily) te lokalnih sredstava priopćavanja. ${ }^{69}$

Što se pak sadržaja oglasa tiče, Komisija smatra da on može sadržavati kratak opis bitnih sastojaka ugovora i načina njegove dodjele zajedno s pozivom da se kontaktira s javnim naručiteljem; u njemu se može uputiti i na dodatne informacije dostupne na internetu ili na zahtjev kod javnog naručitelja; količina informacija mora biti takva da poduzetnik u drugoj državi članici može donijeti odluku o tome hoće li se prijaviti; a ako je ograničen broj sudionika, javni naručitelj mora opisati mehanizam eliminacije. ${ }^{70}$

Javni naručitelji bi se s pravom mogli zapitati kakva je onda uopće razlika između dodjele ugovora na koju se primjenjuju direktive o javnoj nabavi i one koja je izvan njihova područja primjene. Čini se da je razlika jedino u tome da javni naručitelji - unatoč tome što moraju objaviti oglas s minimalnim sadržajem - ne moraju provoditi stroge postupke javne nabave predviđene direktivama o javnoj nabavi. ${ }^{71}$ Kao što je Opći sud potvrdio u svojoj presudi Njemačka i dr./Komisija (T-258/06, EU:T:2010:214, t. 96. u vezi s t. 27. do 29.), Komisijina komunikacija u točki 2.1.2. odluku o prikladnom stupnju i obliku oglašavanja prepušta javnim naručiteljima i ne stvara novu obvezu, različitu od onih koje se na njih već primjenjuju na temelju prava Unije. ${ }^{72}$

interesa, odnosno da se takav interes ne presumira (t. 33. navedene presude) pa je zbog nedostataka dokaza odbio Komisijinu tužbu protiv Irske. komunikacije. Za suprotno stajalište, prema kojem nije potrebno objaviti oglas, vidjeti mišljenje nezavisne odvjetnice E. Sharpston u predmetu Komisija/Finska (C-195/04, EU:C:2007:28, t. 76., 77., 82. do 98.). U navedenom mišljenju nezavisna odvjetnica smatra da se na pitanje razine transparentnosti primjenjuje nacionalno pravo. Nažalost, budući da je presudom Komisijina tužba odbačena zbog postupovnih razloga, Sud se nije osvrnuo na meritum spora i stajališta E. Sharpston. S druge strane, budući da protiv presude Općeg suda Njemačka i dr./Komisija (T-258/06, EU:T:2010:214) nitko nije podnio žalbu, nema pouzdanog izvora o tome koje je stajalište Suda.

72 U istom smislu i Sud navodi u presudi SECAP i dr. (C-147/06 i C-148/06, EU:C:2008:277, t. 30.) da, prije definiranja uvjeta obavijesti o nadmetanju, ocjenu mogućeg prekograničnog interesa ugovora izvan područja primjene direktiva o javnoj nabavi treba provesti javni naručitelj, s tim da njegova ocjena može biti predmet sudskog nadzora. 


\section{ZAKLJUČAK}

U ovom radu analizirani su izvori primarnog prava Unije o javnoj nabavi koji obuhvaćaju pravila UFEU-a (posebice o slobodama kretanja robe, usluga i poslovnog nastana) te načela nediskriminacije, jednakog postupanja, transparentnosti, načela proporcionalnosti i uzajamnog priznavanja.

Kao što je naglašeno, navedeni se izvori prava izravno primjenjuju na sve dodjele ugovora o javnoj nabavi, neovisno o tome je li konkretni ugovor izrijekom isključen iz područja primjene direktiva o javnoj nabavi, primjerice ako je vrijednost konkretnog predmeta nabave niža od propisanih pragova.

Usto valja napomenuti da zakonodavstvo države članice ne treba izričito predviđati obvezu poštovanja tih načela, s obzirom na to da ona proizlaze iz primarnog prava. To stvara dodatan pritisak na javne naručitelje, ali i rizik pri odlučivanju o tome treba li neki ugovor dodijeliti u prilagođenom postupku javne nabave ili ne.

Slijedom toga, javnim se naručiteljima i zakonodavcima država članica kao apsolutni imperativ nameće poznavanje relevantne sudske prakse Suda EU-a kad je riječ o kriterijima za primjenu navedenih načela, kako bi izbjegli povrede svojih obveza na temelju UFEU-a.

\section{LITERATURA}

1. Arrowsmith, S., Bordalo Faustino, P., Heuninckx, B., Treumer, S., Fejø, J., EU Public Procurement Law: an Introduction; University of Nottingham, srpanj 2010., https://www.nottingham.ac.uk/ pprg/documentsarchive/asialinkmaterials/eupublicprocurementlawintroduction.pdf, pristupljeno 29. rujna 2017.

2. Craig, P., de Búrca, G., EU Law: Text, Cases, and Materials, 6. izdanje, Oxford University Press, 2015.

3. Ćapeta, T., Rodin, S., Osnove prava Europske unije na temelju Lisabonskog ugovora, Narodne novine, Zagreb, 2010.

4. Maciejewski, M., Ugovori o javnoj nabavi, Informativni članci o Europskoj uniji, Europski parlament, lipanj 2017., http://www.europarl.europa.eu/atyourservice/hr/displayFtu.html?ftuId=FTU-3.2.2. html, pristupljeno 29. rujna 2017.

5. Medvedović, D., Šprajc, I., Postupak javnih nabavki i pravna zaštita sudionika, Pravo u gospodarstvu god. 4, br. 4, 2003., str. 163.-208.

\section{IZVORI}

\section{Pravni akti}

1. Direktiva Vijeća 93/42/EEZ od 14. lipnja 1993. o medicinskim proizvodima (SL 1993., L 169, str. 1.) (SL, posebno izdanje na hrvatskom jeziku, poglavlje 13., svezak 53., str. 5.).

2. Direktive 96/71/EZ Europskog parlamenta i Vijeća od 16. prosinca 1996. o upućivanju radnika u okviru pružanja usluga (SL 1997., L 18, str. 1.) (SL, posebno izdanje na hrvatskom jeziku, poglavlje 5., svezak 5., str. 127.). 
3. Direktiva 2014/24/EU Europskog parlamenta i Vijeća o javnoj nabavi i o stavljanju izvan snage Direktive 2004/18/EZ (SL 2014., L 94, str. 65.; ispravci SL 2015., L 275, str. 68. i SL 2016., L 311, str. 26.).

4. Direktiva 2014/25/EU Europskog parlamenta i Vijeća od 26. veljače 2014. o nabavi subjekata koji djeluju u sektoru vodnog gospodarstva, energetskom i prometnom sektoru te sektoru poštanskih usluga i stavljanju izvan snage Direktive 2004/17/EZ (SL 2014., 94, str. 243.).

5. Direktiva 2014/23/EU Europskog parlamenta i Vijeća od 26. veljače 2014. o dodjeli ugovorâ o koncesiji (SL 2014., L 94, str. 1. i ispravak SL 2015., L 114, str. 24.).

6. Zakon o javnoj nabavi (Narodne novine, broj 120/2016).

7. Zakon o strancima (Narodne novine, broj 130/2011, 74/2013).

8. Zakona o trgovačkim društvima (Narodne novine, broj 111/1993, 34/1999, 121/1999, 52/2000, 118/2003, 107/2007, 146/2008, 137/2009, 125/2011, 152/2011, 111/2012, 68/2013, 110/2015).

\section{Sudska praksa}

1. Rewe/Bundesmonopolverwaltung für Branntwein, 120/78, EU:C:1979:42.

2. Boussac Saint-Frères, 22/80, EU:C:1980:251.

3. Seco/EVI, 62/81 i 63/81, EU:C:1982:34.

4. Komisija/Francuska, 21/84, EU:C:1985:184.

5. Komisija/Irska, 45/87, EU:C:1988:435.

6. Costanzo, 103/88, EU:C:1989:256.

7. Komisija/Italija, C-3/88, EU:C:1989:606.

8. Du Pont de Nemours Italiana, C-21/88, EU:C:1990:121.

9. Rush Portuguesa, C-113/89, EU:C:1990:142.

10. Laboratori Bruneau/USL RM/24 di Monterotondo, C-351/88, EU:C:1991:304.

11. Komisija/Italija, C-360/89, EU:C:1992:235.

12. Komisija/Danska, C-243/89, EU:C:1993:257.

13. Komisija/Italija, C-272/91, EU:C:1994:167.

14. Komisija/Nizozemska, C-359/93, EU:C:1995:14.

15. Komisija/Belgija, C-87/94, EU:C:1996:161.

16. Unitron Scandinavia i 3-S, C-275/98, EU:C:1999:567.

17. Telaustria, C-324/98, EU:C:2000:669.

18. Vestergaard, C-59/00, EU:C:2001:654.

19. Portugaia Construções, C-164/99, EU:C:2002:40.

20. Coname, C-231/03, EU:C:2005:487.

21. Parking Brixen, C-458/03, EU:C:2005:605.

22. ANAV, C-410/04, EU:C:2006:237.

23. Komisija/Finska, C-195/04, EU:C:2007:28.

24. Medipac-Kazantzidis, C-6/05, EU:C:2007:337.

25. Komisija/Irska, C-507/03, EU:C:2007:676.

26. Laval, C-341/05, EU:C:2007:809. 
27. Komisija/Italija, C-412/04, EU:C:2008:102.

28. SECAP i dr., C-147/06 i C-148/06, EU:C:2008:277.pressetext Nachrichtenagentur, C-454/06, EU:C:2008:351.

29. Komisija/Grčka, C-489/06, EU:C:2009:165.

30. Njemačka i dr./Komisija, T-258/06, EU:T:2010:214.

31. Hervis Sport- és Divatkereskedelmi, C-385/12, EU:C:2014:47.

32. Léger, C-528/13, EU:C:2015:288.

33. Brouillard, C-298/14, EU:C:2015:652.

34. Capoda Import-Export, C-354/14, EU:C:2015:658.

35. Španjolska/Komisija, T-461/13, EU:T:2015:891.

36. Partner Apelski Dariusz, C-324/14, EU:C:2016:214.

37. Dimarso, C-6/15, EU:C:2016:555.

38. Wrocław - Miasto na prawach powiatu, C-406/14, EU:C:2016:562.

39. Borta, C-298/15, EU:C:2017:266. 


\section{DIRECT APPLICATION OF PRIMARY EU LAW RULES AND PRINCIPLES TO AWARDS OF PUBLIC CONTRACTS}

\section{Summary}

The legal horizon of the public procurement area is not limited to the national legislation and the relevant EU directives relating to the public procurement, utilities procurement and concessions. It also comprises certain rules and principles of the EU primary law that apply to all awards of public contracts, as confirmed by the CJEU's case-law. In this article, the author analyses the evolution of the CJEU's case-law with respect to the application of TFEU rules, as well as the principles of equal treatment, non-discrimination, transparency and mutual recognition to awards of public contracts. The violations of those rules and principles can be subject of individual review procedures according to the national law, but also of infringement procedures instituted by the European Commission before the CJEU against Member States.

Keywords: $\quad$ public procurement, principles of public procurement, EU law, transparency 